\title{
THE GEOSPATIAL UNDERSTANDING OF CLIMATE- SMART AGRICULTURE AND REDD+ IMPLEMENTATION: INDIAN PERSPECTIVE
}

\author{
FIROZ AHMAD ${ }^{1 *}$, ASIM FAROOQ 2 , LAXMI GOPARAJU ${ }^{1}$, JAVED RIZVI ${ }^{3}$ \\ ${ }^{1}$ Vindhya Bachao Secretariat, 36/30, Shivpuri Colony, Station Road, Mirzapur-231001, Uttar Pradesh, India; \\ e-mail: adfiroz@yahoo.com \\ ${ }^{2}$ School of Civil and Resource Engineering, University of Science and Technology, Beijing, China \\ ${ }^{3}$ World Agroforestry (ICRAF), South Asia Regional Program, New Delhi, India
}

${ }^{\star}$ Author for correspondence

Abstract

Ahmad F., Farooq A., Goparaju L., Javed R.: The geospatial understanding of Climate-Smart Agriculture and REDD+ implementation: Indian perspective. Ekológia (Bratislava), Vol. 39, No. 1, p. 72-87, 2020.

Geospatial technology has an enormous capacity to analyze large and diversified datasets for evaluating the hidden spatial relationship which provides a better comprehension of the subject and helps significantly in policymaking and planning future strategies.

This study has examined the relationship among diversified remote sensing and GIS datasets such as GHG emission from cropland, rice cultivation area, agro-ecological region, Land use/ Land cover (LULC) categories, long-term NDVI (1982-2006) based negative changes, agriculture vulnerability, drought-prone area and future $(2021,2050)$ climate change anomalies (RCP-6) of India for better understanding and knowledge of the GHG emission scenario, vegetation health, LULC, agriculture vulnerability, and future climate change impact. The LULC analysis revealed that $49.6 \%$ (1 $628959 \mathrm{~km}^{2}$ ) of the geographical area was found to be under category 'cropland'. The $32.5 \%$ of the total cropland areas are used for rice cultivation whereas around $76 \%$ of this rice cultivation area is producing high GHG emission (>1000 $\mathrm{Mg} \mathrm{CO}_{2}$ e/yr.). LULC categories 'Cropland' and 'Plantation' show the long-term (1982-2006) negative change equivalent to 19.7 and $70.2 \%$ respectively. Similarly, around $56 \%$ of LULC categories representing the forest show the long-term negative change whereas the maximum change $\left(139867 \mathrm{~km}^{2}\right)$ was found in the category of 'Deciduous Broadleaf Forest'. The $30.6 \%$ of the LULC category of 'cropland' falls in very high agriculture vulnerable areas whereas $31.7 \%$ of the same category falls in the drought-prone area. The significant increase in temperature and abrupt rainfall patterns were observed during Kharif and Rabi seasons in the future. Such variation of climate parameter in the future not only adversely affect the agriculture crop production but also the natural vegetation of India.

The outcomes of the present study would support the policymakers of India to implement the climate-smart agriculture (CSA) and REDD+ on an urgent priority based on a proper evaluation of the socio-economic condition of the poor people. It will certainly help in the reduction of GHG emission, forest amelioration, will bring the resilience in livelihood and mitigate the poverty among the rural communities for the betterment of people.

Key words: GHG, LULC, NDVI based negative change, agriculture vulnerability, climate anomalies, India. 


\section{Introduction}

Greenhouse gases (GHGs) such as carbon dioxide $\left(\mathrm{CO}_{2}\right)$, methane $\left(\mathrm{CH}_{4}\right)$ and nitrous oxide $\left(\mathrm{N}_{2} \mathrm{O}\right)$ are increasing on the Earth's surface these days and significantly increasing the atmospheric temperature and rainfall pattern (IPCC, 2014). The total $\mathrm{CO}_{2}$ equivalent emission estimates in India were about 2008.67 Tg (without land use, land-use change, and forestry (LULUCF) sector) (Energy: 69\%; Agriculture: 19\%; Industrial process: $9 \%$ and Waste: 3\%) whereas the estimates of emissions were of the order of $1831.65 \mathrm{Tg} \mathrm{CO}_{2}$ equivalent (with LULUCF sector) which significantly reflect LULUCF as a whole acts as a sink for $\mathrm{CO}_{2}$ (Sharma et al., 2011). The study of Baur et al. (2015) showed that the change in the LULC pattern has a very significant connection to GHG emission. Various agricultural activities such as land clearing, cultivation of agriculture crops, irrigation, animal husbandry, fisheries, and aquaculture have a significant impact on the emission of GHGs and the consequent climate change (IPCC, 2007).

The agro-ecosystem plays an important role in the global share of GHG emissions (Hou et al., 2012). Agriculture alone is responsible for about $50 \%$ of the global anthropogenic gases like $\mathrm{CH}_{4}$, and for $60 \%$ of $\mathrm{N}_{2} \mathrm{O}$ (IPCC, 2007). Agricultural $\mathrm{N}_{2} \mathrm{O}$ emissions are predicted to increase (23 to 60\%) by the year 2030 due to increased chemical and manure nitrogen inputs (Maris et al., 2016). Furthermore, paddy lands are considered to be an important source of anthropogenic $\mathrm{CH}_{4}, \mathrm{~N}_{2} \mathrm{O}$, and $\mathrm{CO}_{2}$ and will increase $\mathrm{CH}_{4}$ from rice fields due to an increase in the rice sown area in the future (Cai et al., 2007).

Agriculture plays an important role in the Indian economy and supports significantly to the rural livelihood structure of the country. It provides employment to $50 \%$ of the country's population and supports 18\% of the country's GDP (Madhusudhan, 2015). Drought is further an important challenge to the sustainable agriculture and food security in India which adversely affects the small and marginal farmers. Indian farmers/cultivators are extremely vulnerable to climate change because roughly two-thirds of the cultivated land is rain-fed and fully dependent on the monsoon rainfall (http://nraa.gov.in/). Climate-smart agriculture and REDD+ were implemented in part of Kenya which manifests regulatory policy framework is supportive of climate-smart agriculture, containing policies aimed at addressing food security in addition to climate change adaptation and mitigation strategies (Dooley, Chapman, 2014). Geospatial technology has adequate capacity to analyze the raster/ vector datasets and examine the hidden spatial relationship in the GIS domain which provides a better understanding of the subject and helps significantly in policy planning and making sustainable strategies (Ahmad, Goparaju, 2019).

\section{Why Climate-Smart Agriculture (CSA) and REDD+ implementation?}

1. The GHG emissions are significant over India which needs to be reduced as per the international treaty.

2. India has endorsed the long-term target of limiting the temperature rise to under $2^{\circ} \mathrm{C}(\mathrm{GoI}, 2008)$ and has also made voluntary commitment for reducing the emission intensity of GDP in the year 2020 by $20-25 \%$ below that in the year 2005 at COP15 in Copenhagen (Shukla, Dhar, 2016).

3. To reduce the climate change impact and strengthen the food security and resilience in livelihood (Lipper et al., 2014). 
4. To achieve a social, economic and environmental goal by optimizing land productivity.

5. REDD+ has tremendous potential to contribute to climate change mitigation, poverty alleviation, conserving biodiversity and step towards sustainable ecosystem services (UNFCC, 2012).

In the climate change scenario, climate-smart agriculture (CSA) will be a viable solution that has enormous potential to provide resilience to the poor marginalized farmers of India suffering from the climate-induced crop failure and will significantly help to mitigate GHG emission. Climate-smart agriculture (CSA) is an approach to transforming and reorienting agricultural development under the new realities of climate change (Lipper et al., 2014). REDD+ is a mechanism that aims to provide an economic incentive for the countries to protect, rather than cut down, their forests in order to reduce greenhouse gas emissions (Byrn et al., 2013) apart from conservation, sustainable management, and the enhancement of forest. Climate-smart agriculture (CSA) could be an integral part of India's REDD+ strategy in terms of (i) on-farm actions that indirectly reduce emissions from deforestation and forest deterioration; and (ii) policy, legal, and institutional actions at county, state, district and village levels that support investment/technology/ guideline in and adoption of the climate-smart agricultural practices in food security, poverty mitigation, reviving the diminishing livelihood, increasing the tangible and nontangible service benefits in the rural area, optimizing the soil fertility, magnifying the farm household resilience, ameliorate the existing eco-system, protecting the existing biodiversity, and reducing the future climate change impact.

Widespread changes in rainfall and temperature patterns as well as frequent drought and floods threaten agricultural production and increase the vulnerability of people dependent on agriculture for their livelihoods. Agriculture crop production will be challenged to continue the increasing global crop production to meet the nutritional requirements of an increasing population and help achieve food security to the existing hungry people, while at the same time limiting cropland expansion and containing damages to the natural resources and other ecosystems (Falkenmark et al., 2009). Climate change (2007) assessment report reveals that the majority of hungry people living today face absolute poverty and are agriculture dependent suffer from the negative impact of agricultural production and by chronic water shortages due to ongoing and future climate changes. The agricultural production statistics show that the rates of food grain production have recently declined in several countries in spite of international efforts to optimize the global food security (Funk, Brown, 2009).

Climate plays a major factor and controls the distributions and growth of plant species and vegetation (Sykes, 2009). Kharif and Rabi are the two cropping pattern season which is adopted in many Asian monsoon countries including India. The cropping season of Kharif starts from June-October during the south-west monsoon and the Rabi cropping season is from October-March (winter). In India, rainfall, temperature, and its spatial distribution pattern is an influential factor which affects the growth of agriculture productivity, economy, and livelihood (Bothale, Katpatal, 2014). Vegetation in any area at a significant scale has been playing a vital role in balancing the stability of sustainable habitat and has a relationship with the existing ecosystem and climate (Bing et al., 2014).

The objectives of the present study are to create maps in GIS environment, examine the spatial distribution patterns and relationship/query of diversified datasets such as GHG emission, rice-producing area, agro-ecological regions, land use/ land cover (LULC), NDVI based negative change, agriculture vulnerability, drought-prone area and future $(2021,2050)$ annual, Kharif and Rabi season climate change anomalies (RCP-6) over India. 


\section{Material and method}

\section{Study area}

The study area includes the entire terrestrial land of India with geo coordinate $6^{\circ} 44^{\prime} \mathrm{N}$ to $35^{\circ} 30^{\prime} \mathrm{N}$ latitude and $68^{\circ} 07^{\prime} \mathrm{E}$ to $97^{\circ} 25^{\prime} \mathrm{E}$ longitude. The vegetation of India varies significantly in all diversified ecological and geographical regions based upon climatic conditions, edaphic and topographical variation which is reflected in the form of its structural complexity, species diversity, productive and protective characteristics. Over 60 percent of India's total land is under agriculture and nearly 23 percent covered by forests (http://www.fao.org/india/fao-in-india/india-at-a-glance/en/). Kharif crops are cultivated during the monsoon season. The rice cultivations in the waterlogged area are the important source of GHG emission whereas it magnifies due to the use of inorganic fertilizer widely practiced to enhance the agriculture output. India is a geographically diverse country surrounded by Himalaya's ranges, Thar desert, Gangetic delta, and Deccan Plateau in North, West, East, and South respectively and home of various ecosystems which retain vast agro-ecological diversity.

\section{Data acquisition and processing}

In the present study, we have used the various dataset from a diversified source are given in Table 1.

We have used the circa 2000 estimates of Greenhouse gas (GHG) emissions (due to rice cultivation, peatland drainage, and N-fertilizer application) (Carlson et al., 2017) for better comprehension of GHG scenario in India. The map was brought into the GIS environment by digitizing all categories over India and assigned respective values (Fig. 1) for understanding the spatial pattern and their distribution. The data utilized for GHG emissions by coupling biophysical models with 5-arc-minute resolution data on land surface attributes and crop harvest and management (Carlson et al., 2017). The $\mathrm{CH}_{4}$ emissions from paddy (flooded) rice cultivation, $\mathrm{CO}_{2}, \mathrm{~N}_{2} \mathrm{O}$ and $\mathrm{CH}_{4}$ flow from agricultural peatland draining, and direct and indirect $\mathrm{N}_{2} \mathrm{O}$ emissions from synthetic $\mathrm{N}$ fertilizer and manure application. This flow accounts for the majority of GHG emissions from cropland agriculture (http://faostat3.fao.org) but excludes certain emissions sources (for example, energy for fertilizer manufacture, liming). The approach significantly reflects a crop-specific subnational assessment of how agricultural management practices interact with biophysical characteristics to generate diverse patterns of GHG emissions (Carlson et al., 2016). The rice cultivation areas of India (http://maps.unomaha.edu/Peterson/geog1000/MapLinks/India.htm) were digitized and brought into the GIS domain for further analysis.

The agro-ecological region map of India (Bandyopadhyay et al., 2009) which was cited by Ahmad et al. (2018) and all categories were brought under the GIS domain. The high Greenhouse gas (GHG) emission (>1000) category was overlaid over the agro-ecological region map and was given in figure for further analysis (Fig. 2).

We have utilized the Land use and land cover (LULC) data for the year 2005 (https://daac.ornl.gov/VEGETATION/ guides/Decadal_LULC_India.html) having a 100-meter resolution for India (Roy et al., 2015). Most of the LULC class categories exhibit accuracies more than $90 \%$ whereas overall mapping accuracy and Kappa accuracy were $94.46 \%$ and 0.9445

T a b le 1. Various datasets and the sources used in this study.

\begin{tabular}{|l|l|}
\hline Data used & Source/References \\
\hline GHG emission from cropland & Carlson et al., 2017 \\
\hline Rice cultivation area & $\begin{array}{l}\text { http://maps.unomaha.edu/Peterson/geog1000/Map- } \\
\text { Links/India.htm }\end{array}$ \\
\hline Agro-ecological region map of India & $\begin{array}{l}\text { Bandyopadhyay et al., 2009 (Cited by Ahmad et al., } \\
2018)\end{array}$ \\
\hline Long term NDVI (1982-2006) based negative changes & Geospatial world, 2012 \\
\hline Land use/ Land cover (LULC) & Roy et al., 2015 \\
\hline Agriculture vulnerability & Rao et al., 2013 \\
\hline Drought prone area & $\begin{array}{l}\text { https://www.mapsofindia.com/maps/india/natural- } \\
\text { hazard.htm }\end{array}$ \\
\hline Future (2021, 2050) climate change anomalies (RCP-6) & NCAR GIS Program, 2012 \\
\hline
\end{tabular}




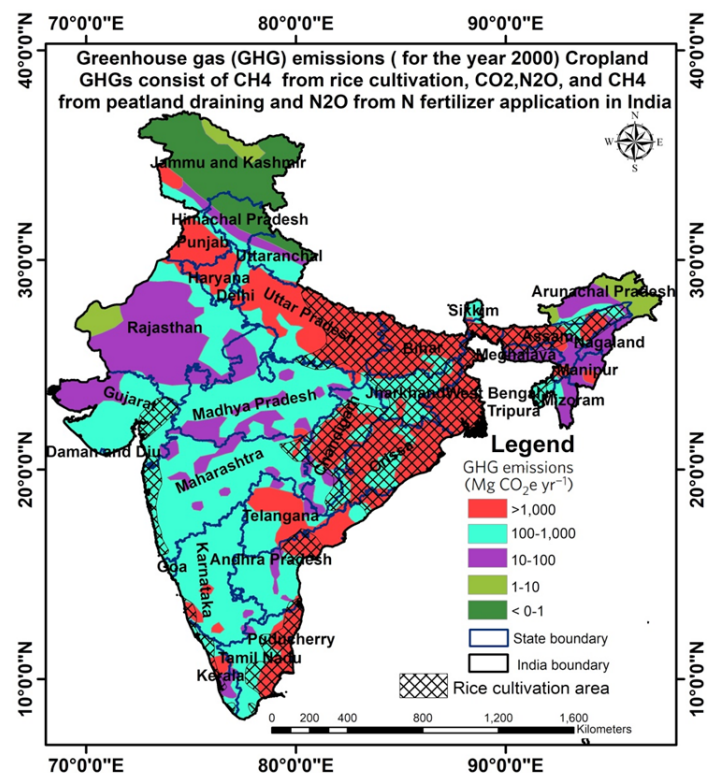

Fig. 1. Greenhouse gas (GHG) emissions (due to rice cultivation, peatland drainage and N-fertilizer application) for the year 2000 in India (Carlson et al., 2017).

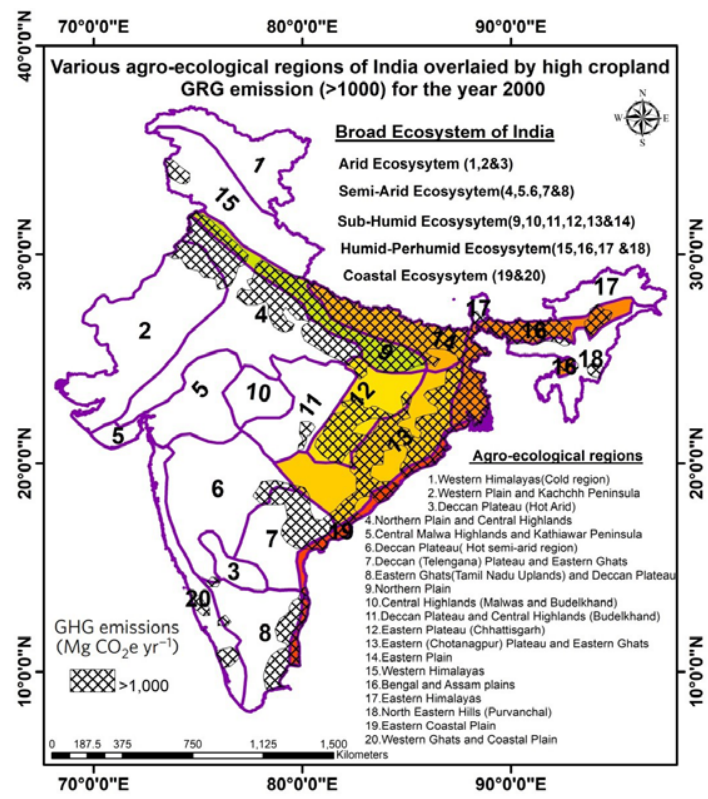

Fig. 2. Agro-ecological regions of India vs. high cropland GHG emission (>1000). respectively for the year 2005 LULC map (Roy et al., 2015).

The NDVI value indicates that vegetation growth and vigor significantly reflects the health of vegetation. Long-term (1982-2006) NDVI map (Geospatial world, 2012) based on NOAAAVHRR data with the spatial resolution of $8 \mathrm{~km}$ was utilized in this study, the trend of negative change was brought into the GIS domain. In this study NDVI variations, only Max NDVI value was used (Holben, 1986) and zonal statistics were calculated using Spatial Analyst Tool in ArcGIS (ver.10.0) to determine variations in NDVI which manifest the long-term (1982-2006) change (Geospatial world, 2012). The Land use/Land cover (LULC) categories map (2005) overlaid by longterm NDVI based negative change areas over India are given in Fig. 3.

The agriculture vulnerability of India (Rao et al., 2013) to climate change (2021-2050) map was brought into the GIS environment (Fig. 4).

The drought-prone area was digitized from the Natural Hazard map of India (https://www. mapsofindia.com/maps/india/natural-hazard. htm) and overlaid over very high agriculture vulnerability map for better understanding (Fig. 5).

We have downloaded the point grid monthly temperature and precipitation anomalies (climate change scenario) data for the year 2021 and 2050 analyzed with the base period 1986-2005 over India using the RCP-6 scenario model (NCAR GIS Program, 2012). In the first step, the month-wise temperature and rainfall surface were produced from the point vector file using the kriging interpolation technique. Kriging is an advanced geostatistical procedure was performed in ArcMap using the spherical semivariogram model that generates the surface from a scattered set of $z$-points values based on interpolation executed by a Gaussian process. The Kharif season temperature and precipitation anomalies were produced by integrating June to October month-wise respective data because the sowing season starts in the month of JuneJuly and harvesting season ends in the month of September to October (https://keydifferences. com/difference-between-kharif-and-rabi-crops. html). Similarly, the Rabi season temperature and precipitation anomalies were produced by integrating October to March month-wise respective data. The anomalies of Kharif, Rabi and annual temperature and precipitation prediction for the year 2021 and 2050 are given from Fig. 6 to Fig. 17 for further analysis. 


\section{Result and discussion}

The analysis of Greenhouse gas (GHG) emissions

The evaluation of Greenhouse gas (GHG) emissions $\left(\mathrm{Mg} \mathrm{CO}_{2} \mathrm{e} /\right.$ yr.) especially from cropland for the year 2000 over India shows that $27 \%$ of the total geographical area of India is producing GHG greater than 1000, followed by $44 \%$ of area $100-1000,19 \%$ of area $10-100$ and rest $10 \%$ are less than 10. A similar observation of GHG emissions has been reported from agriculture (INCCA, 2010). Most of the highest Greenhouse gas (GHG) emissions (>1000) states are Punjab, Haryana, Uttar Pradesh, Bihar, West Bengal, Assam Orissa, Chhattisgarh, Telangana, Andhra Pradesh and Tamil Nadu (Fig. 1).

The analysis of agro-ecological regions

The analysis of available data from various agro-ecological region of India with Greenhouse gas (GHG) emissions scenario of the year 2000 reflects the categories "Northern plain", "Eastern plain", "Eastern Plateau (Chhattisgarh)", "Eastern (Chotanagpur) Plateau and Eastern Ghats" and "Bengal and Assam plains" (Fig. 2) are showing high GHG emission (>1000 $\mathrm{Mg} \mathrm{CO}_{2} \mathrm{e} / \mathrm{yr}$.). These agro-ecological regions of India are responsible for approximately $73 \%$ of high GHG emission



Fig. 3. Land use/Land cover (LULC) categories map (2005) overlaid by long term NDVI based negative change area of India.

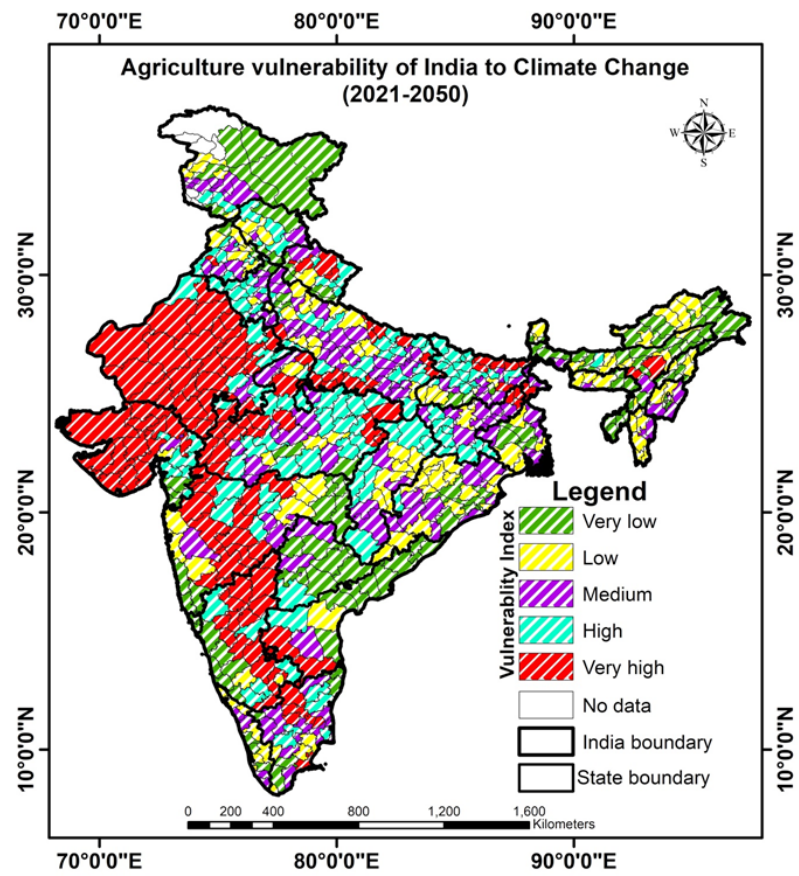

Fig. 4. Agriculture vulnerability of India (Rao et al., 2013). 


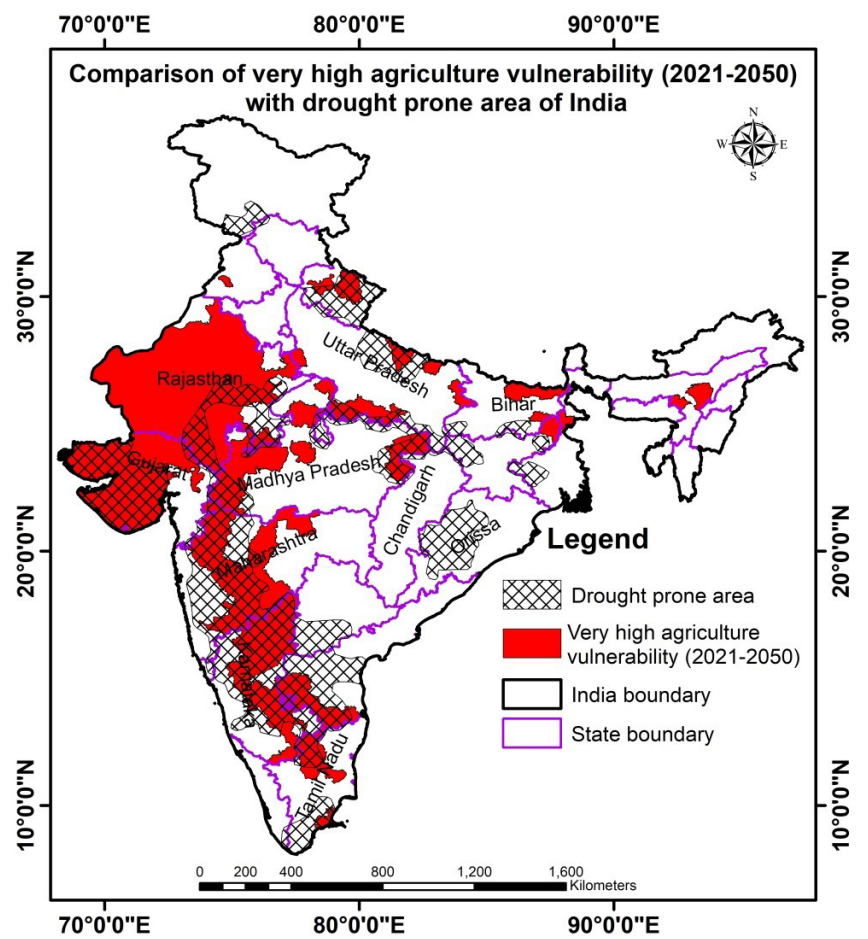

Fig. 5. Very high agriculture vulnerability vs. drought-prone area of India.
(>1000 $\mathrm{Mg} \mathrm{CO}_{2}$ e/yr.) from cropland. The GHG emission from methane (Metric ton) reported in India in the rice field varies significantly from 3.3 to 37.5 as per the report of various scientists (Pathak et al., 2014). Hou et al. (2012) also found similar observation where they found various agro-ecosystems plays a significant role in the GHG emission.

The analysis of LULC categories

The analysis of LULC categories of India revealed that around $49.6 \%$ (1 628 $959 \mathrm{~km}^{2}$ ) of the geographical area was found to be under category 'cropland' and $2.4 \%\left(79238 \mathrm{~km}^{2}\right)$ area as 'plantation' category. The cross-evaluation of LULC

categories with the rice cultivation area revealed that $32.5 \%$ of the LULC category of 'cropland' is used for the rice cultivation area. Furthermore, around $76 \%$ of this rice cultivation area is producing high GHG emission ( $>1000 \mathrm{Mg} \mathrm{CO}_{2} \mathrm{e} / \mathrm{yr}$.) is a matter of serious concern. The agriculture sector such as the LULC categories 'Cropland' and 'Plantation' shows the negative change equivalent to 19.7 and $70.2 \%$ respectively when it was compared with the total area of the respective category (Table 2). Land use and land cover map categories representing the forest were merged (except plantation and scrubland). The total forest area for the year 2005 in India was found to be $22 \%$ of the total geographical area. These forest areas were evaluated with long-term NDVI based analysis (Table 2). Around 56\% of these forest shows the trend of negative change. This means that these forest categories have deteriorated a lot in the long run. Significant negative changes (in term of forest area) were found to be maximum over the category of 'Deciduous Broadleaf Forest' (139867 km²) followed by 'Evergreen Broadleaf Forest' (116926 km²), 'Mixed Forest' (89 $321 \mathrm{~km}^{2}$ ), 'Deciduous Needleleaf Forest' (45 $196 \mathrm{~km}^{2}$ ) and 'Mangrove Forest' (659 $\mathrm{km}^{2}$ ). Furthermore, the Western Ghats of the state of Kerala and Karnataka, all North-Eastern states, Orissa, Telangana, Jharkhand, Maharashtra, Chhattisgarh, Uttrakhand, and Himachal Pradesh state's forest showed that the negative change between the period 1982 to 2006 which is a serious issue. A similar observation was found where 46 lakh hectares of forests in India lost 
$\mathrm{T} \mathrm{a} \mathrm{b}$ le 2. The area statistics of various categories of LULC of India with NDVI based negative change.

\begin{tabular}{|l|c|c|c|}
\hline \multirow{2}{*}{$\begin{array}{c}\text { Land use and land cover map of } \\
\text { India for 2005 }\end{array}$} & Total area & $\begin{array}{c}\text { * } \\
\text { Total negative change } \\
\text { area }^{*}\end{array}$ & Negative change (\%) \\
\cline { 2 - 4 } & & 139867 & 44.4 \\
\hline 1- Deciduous Broadleaf Forest & 315362 & 321706 & 19.7 \\
\hline 2- Cropland & 1628959 & 13723 & 29.0 \\
\hline 3- Built-up Land & 47255 & 89321 & 58.7 \\
\hline 4- Mixed Forest & 152198 & 49407 & 26.4 \\
\hline 5- Shrubland & 187358 & 2127 & 2.1 \\
\hline 6- Barren Land & 101737 & 21928 & 9.8 \\
\hline 7- Fallow Land & 224083 & 2263 & 5.4 \\
\hline 8- Wasteland & 41611 & 32175 & 70.2 \\
\hline 9- Water Bodies & 101080 & 55660 & 24.5 \\
\hline 10- Plantations & 79238 & 53 & 73.7 \\
\hline 11- Aquaculture & 215 & 659 & 100.0 \\
\hline 12- Mangrove Forest & 894 & 80 & 18.9 \\
\hline 13- Salt Pan & 80 & 10442 & 65.2 \\
\hline 14- Grassland & 55247 & 116926 & 78.5 \\
\hline 15- Evergreen Broadleaf Forest & 179225 & 45196 & 16.8 \\
\hline 16- Deciduous Needleleaf Forest & 57575 & 635 & 80.1 \\
\hline 17- Permanent Wetlands & 3791 & 880 & \\
\hline 18- Snow \& Ice & 91617 & 15802 & \\
\hline 19- Evergreen Needleleaf Forest & 19738 & & \\
\hline
\end{tabular}

greenness between the period 2001 to 2014 (Nilesh, 2018). Such analysis gives emphasis on implementing REDD+ as early as possible. Similar findings of negative change were reported by Chakraborty et al. (2018) utilizing the long-term MODIS NDVI data. The negative change in vegetation not only leads to degradation in the natural forest but also into the agriculture and plantation sector adversely impact food security, livelihood resilience, regional biodiversity, and the climate.

\section{The analysis of agriculture vulnerability}

The prediction of agriculture vulnerability of India (2021-2050) shows that 26.5, 18.3, 16.6, 13.9 and $23.4 \%$ of the geographical area of India will be very high, high, medium, low and very low vulnerable to agriculture respectively. The significant very high agriculture vulnerability will be more pronounced on the western side of India. The Rajasthan, Gujarat, Maharashtra and Karnataka, part of Tamil Nadu and Andhra Pradesh states will be the highest sufferer in the future. Furthermore, these areas fall on arid and semi-arid agro-ecosystem region characterized by severe weather conditions such as low rainfall pattern, high solar radiation, high wind velocity, and increased evapotranspiration whereas productivity potential of the land is also usually low due to immature, structure-less, and very coarse texture of soil with low water retention capacity and poor nutrient status (Ahmad et al., 2018). The drought- 

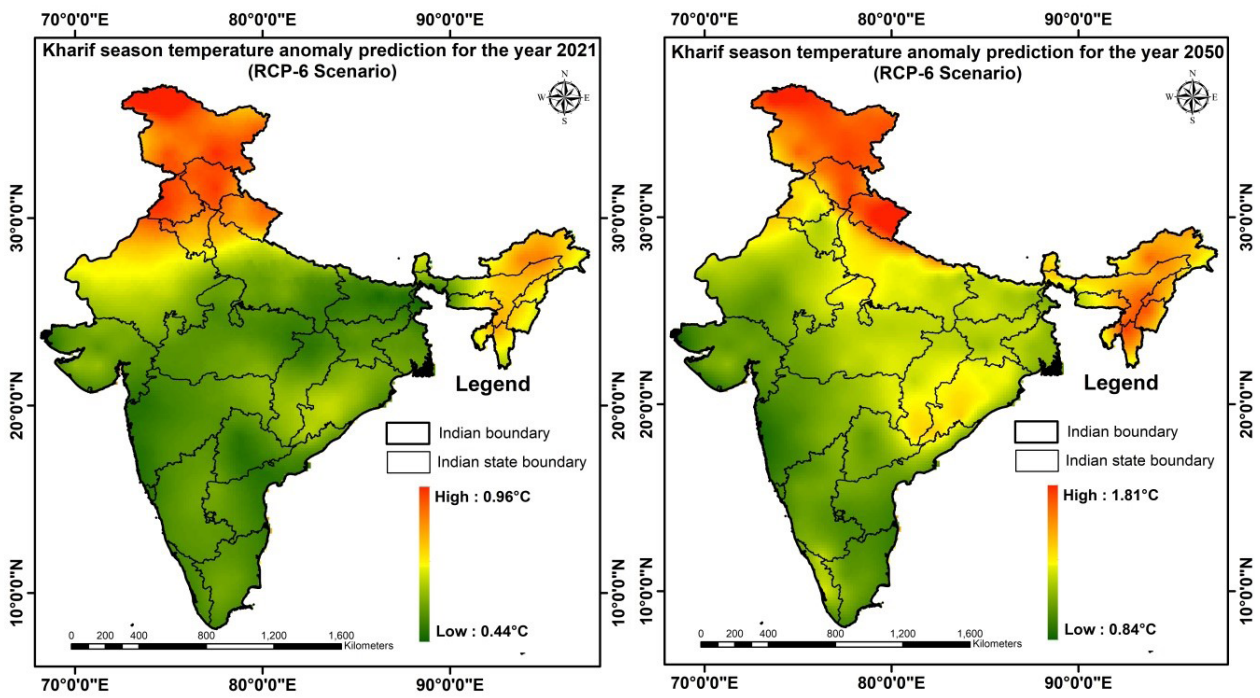

Fig. 6. Kharif season temperature anomaly (2021).

Fig. 7. Kharif season temperature anomaly (2050).
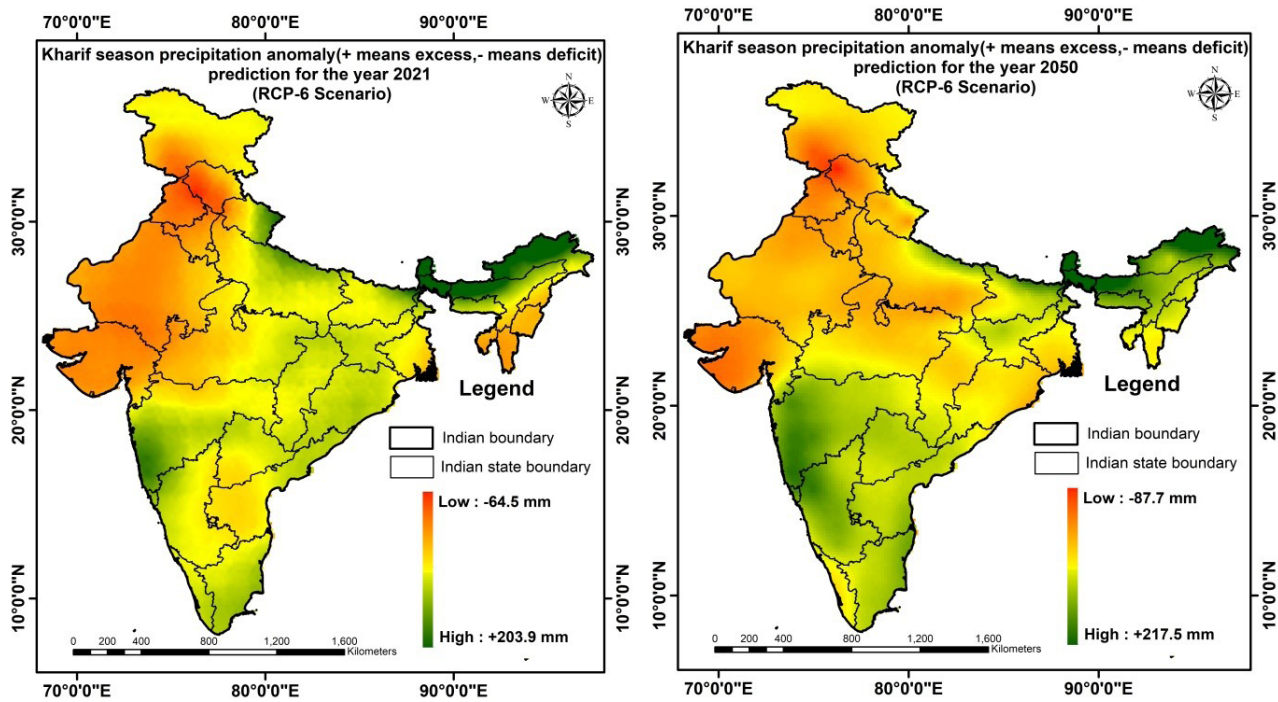

Fig. 8. Kharif season precipitation anomaly (2021).

Fig. 9. Kharif season precipitation anomaly (2050).

prone area analysis shows that $38 \%$ of the geographical area of India is drought-prone. The spatial pattern is more scattered over India whereas it is more pronounced over the western and southern regions of India characterized over the arid and semi-arid agro-ecosystem region (Fig. 2). The cross-comparison of the drought-prone area with agriculture vulnerability 


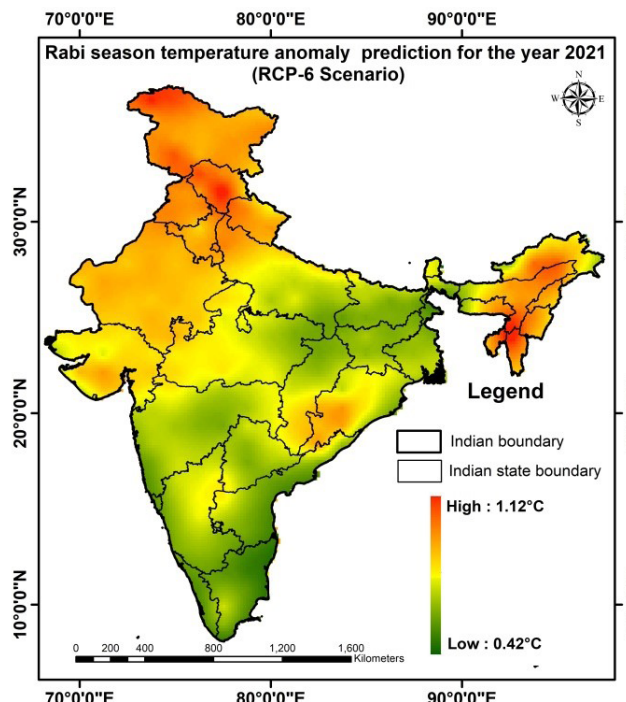

Fig. 10. Rabi season temperature anomaly (2021).

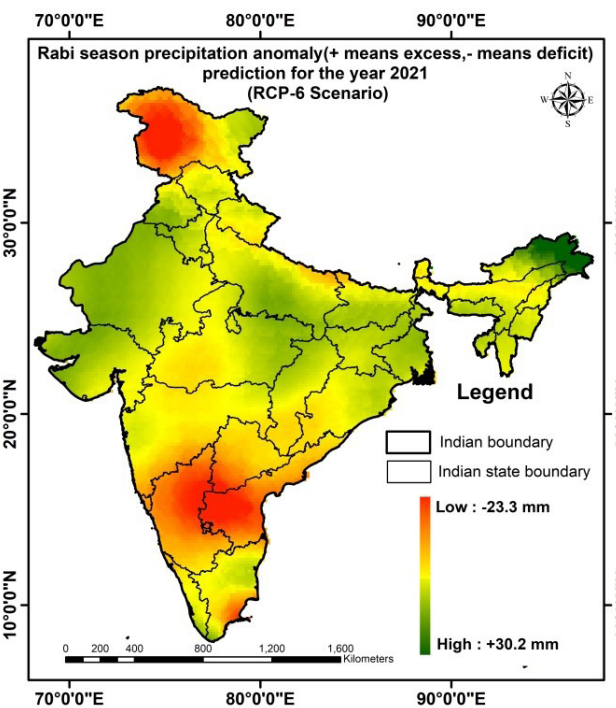

Fig. 12. Rabi season precipitation anomaly (2021).

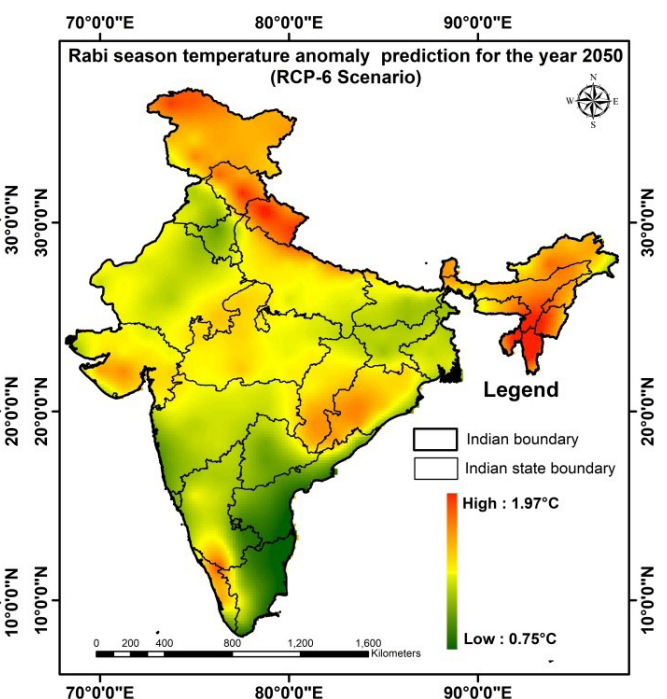

Fig. 11. Rabi season temperature anomaly (2050).



Fig. 13. Rabi season precipitation anomaly (2050).

map shows 51\% drought-prone area falls on very high agriculture vulnerable area. A similar vulnerability assessment to drought was reported by Zarafshani et al., 2016.

We have also cross-tabulated the LULC category of 'cropland' with the drought-prone area and agriculture venerability. The analysis shows that $30.6 \%$ of the LULC category of 


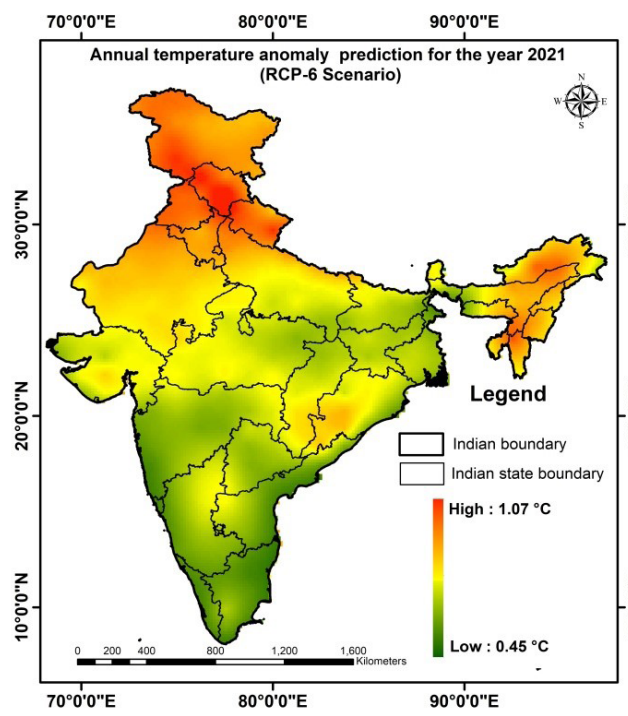

Fig. 14. Annual temperature anomaly (2021).

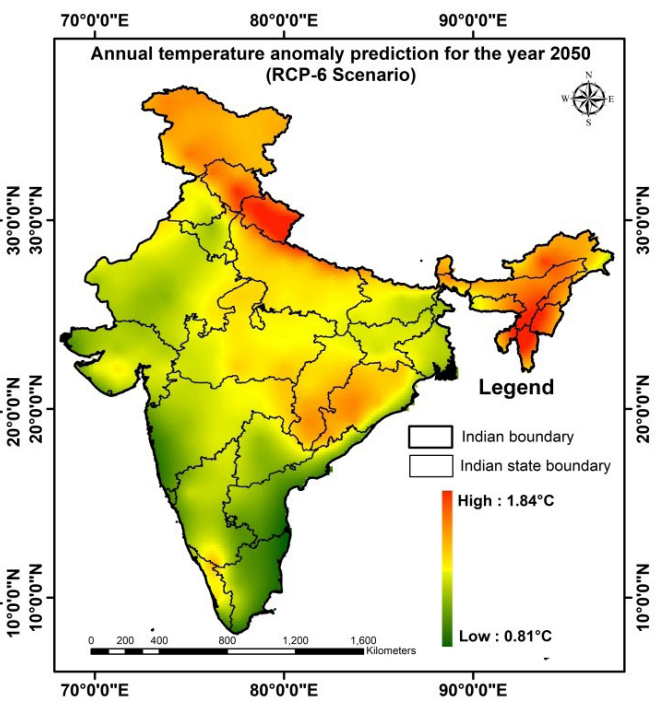

Fig. 15. Annual temperature anomaly (2050).

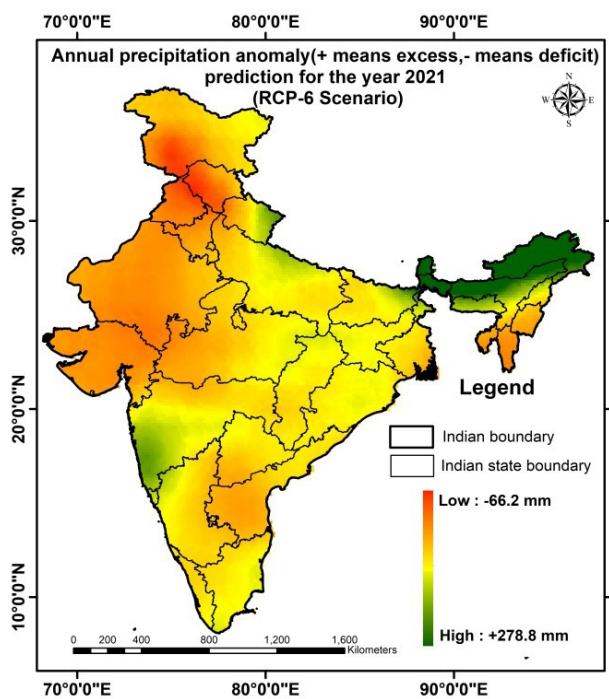

Fig. 16. Annual precipitation anomaly (2021).

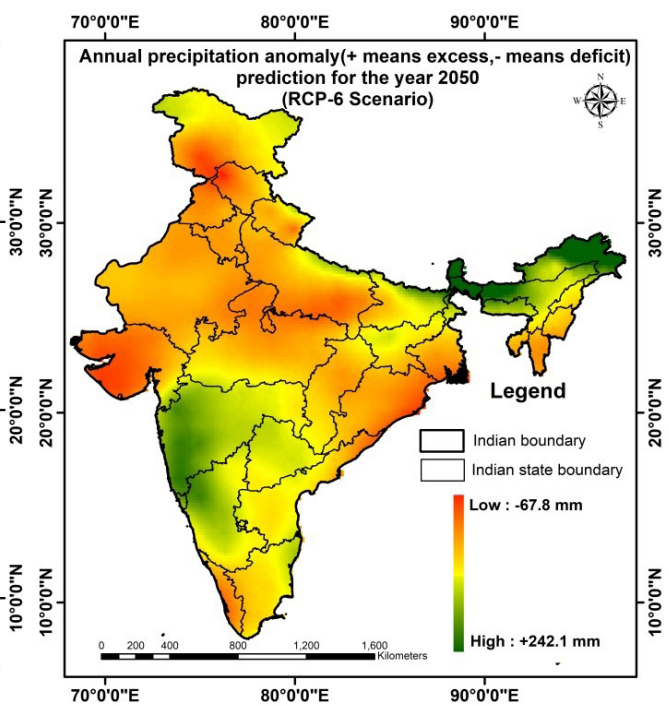

Fig. 17. Annual precipitation anomaly (2050).

'cropland' falls on very high agriculture vulnerable area whereas $31.7 \%$ of the same category falls on the drought-prone area. The analysis further revealed that $17.2 \%$ of the LULC category of 'cropland' falls on both high agriculture vulnerable areas and drought-prone areas will face tremendous pressure in the future as far as agricultural production is a concern. 
The analysis of predicted Kharif, Rabi and annual climate data such as temperature and precipitation anomalies for the year 2021 and 2050 shows some interesting trends over India. During Kharif season the temperature is showing an increasing trend over India with the range of ( 0.44 to 0.98 $\left.{ }^{\circ} \mathrm{C}\right),\left(0.84\right.$ to $1.81^{\circ} \mathrm{C}$ ) for the year 2021 and 2050 respectively will significantly impact and will reduce the yield of Kharif crop such as rice, maize, soybean etc. In each degree-Celsius increase in mean temperature would, on average will decrease the yields of rice by $3.2 \%$, maize by $7.4 \%$, and soybean by $3.1 \%$ (Zhao et al., 2017). Furthermore, high-temperature increase during the Kharif season in the year 2021 is significant over the state of Jammu and Kashmir, Himachal Pradesh, Uttarakhand, Punjab and Haryana and Northern part of Rajasthan and most of the North East states of India. In the year 2050 temperature will be significantly high with greater intensity over the same state of India where the temperature was observed increasing for the year 2021 whereas, it further intensified in the new area of the state Chhattisgarh, Orissa and North Western Uttar Pradesh. The precipitation spatial pattern and variation during Kharif season (2021) with deficit in precipitation was observed over Himachal Pradesh, Punjab, Haryana, Rajasthan, Gujarat, western Madhya Pradesh and Southern part of North-East states of India whereas further precipitation deficit was observed (2050) in the southern part of Uttar Pradesh and northern part of Madhya Pradesh.

During Rabi season the temperature is showing an increasing trend over India with the range of $\left(0.42\right.$ to $\left.1.12^{\circ} \mathrm{C}\right),\left(0.75\right.$ to $\left.1.97^{\circ} \mathrm{C}\right)$ for the year 2021 and 2050 respectively. Furthermore, high-temperature increase during the rabi season in the year 2021 is significant over the state of Jammu and Kashmir, Himachal Pradesh, Uttarakhand, Punjab, Haryana Rajasthan, Gujarat, part of Orissa, part of Chhattisgarh and most of the North East states of India. In the year 2050 temperature will significantly increase in the new area of Western Ghat of India with the coastal state of Kerala and Karnataka. The precipitation deficit in the year 2021 was noticeable in the state of Karnataka, Andhra Pradesh and western part of Jammu Kashmir. In the year 2050, the precipitation deficit will be in the eastern coastal states and North-East states of India whereas it will be more critical for the state of Tamil Nadu and Kerala. The study of Zhao et al. 2017 shows that Rabi season crops such as wheat yield will reduce by $6 \%$ by an increase in each degree temperature. We can finally conclude that the temperature increase and precipitation variation during Kharif and Rabi season in the future will significantly reduce the Kharif and Rabi crops such as rice, wheat, barley, and mustard production and will challenge the future food security and livelihood resilience.

The annual temperature is showing an increasing trend over India with the range of ( 0.45 to $\left.1.07^{\circ} \mathrm{C}\right),\left(0.81\right.$ to $\left.1.84^{\circ} \mathrm{C}\right)$ for the year 2021 and 2050 respectively whereas precipitation variation is also being observed during the same base years. The annual temperature increases in the year 2021 are notable over the northern states (Jammu and Kashmir, Himachal Pradesh, Uttarakhand, Punjab, Haryana, and Rajasthan), the northern region of Uttar Pradesh, the southern part of Orissa and North-East states in India. In the year 2050, it was further intensified in the same area except for Rajasthan. The precipitation deficit in the year 2021 was found in the northwestern region of India whereas it is more pronounced in the state of Jammu and Kashmir, Himachal Pradesh and Haryana. Similarly, in the year 2050 precipitation deficit is more 
scattered over India whereas it is more crucial for the state of Gujarat, Kerala, the southern region of Uttar Pradesh, the southwestern region of Jammu and Kashmir, the north region of Madhya Pradesh, coastal region of Orissa and West Bengal.

\section{Climate change impacts and the need for Climate-Smart Agriculture (CSA) and REDD+}

Increasing concentrations of greenhouse gases (GHGs) in the atmosphere are significantly maneuvering climate change. A study conducted by NASA reveals that the global temperature has been increased by approximately

$1{ }^{\circ} \mathrm{C}$ in the year 2016 whereas it shows the significantly increasing trend (https://climate.nasa. gov/vital-signs/global-temperature/). A study conducted by Lal et al., 1995 predicted the increase in temperature for the year 2040 with an increase of $0.7-1.0^{\circ} \mathrm{C}$ annual mean maximum and minimum surface air temperatures. The study on climate change by Ray, De (2003) revealed that there will be an occurrence of extreme events in the future. Climate change directly impacts lives of farmers/poor people in India by causing lower crop yields especially for rice and wheat (Anand, Khetarpal, 2015), threatening the food security and livelihood, whereas it has the potential to create a wide range of economic impacts (Gupta et al., 2012). Some impacts will gradually affect economic processes, such as the effect of increasing temperature on energy demand whereas others may come as extreme events, such as sudden floods, forest fires and their future events with greater intensity. Indiass forests are degrading at an alarming pace whereas they are significantly losing their greenness in the long run (Chakraborty et al., 2018). The deforestation and forest degradation (REDD+) will be a very effective mechanism for mitigating climate change impact by providing financial incentives for reducing deforestation and forest degradation to the rural and forest-dependent communities from international financial sources (Ravindranath et al., 2012). There is a need to find out the approach/ mechanism to accelerate a process from country level, state level, district level to the village level. This will greatly enhance the livelihood of the rural tribal/poor people and significantly mitigate the poverty among them. Furthermore, India has adopted agroforestry policy in the year 2014 which will significantly support the objective of climate-smart agriculture (https:/csa.guide/csa/national-agroforestry-policy-of-india) keeping the strategies to expand the use of agroforestry practices outside the natural forest's boundary (NAP, 2014). Such practices on our land-use system will also satisfy the demand for food, fuel, and fodder to increasing population in a sustainable manner for the survival and prosperity of humanity.

Based on our study we can conclude that the existing land, agriculture, forest, and agroforestry policies should be significantly maneuvered towards CSA and REDD+ to reduce GHG emissions, to protect our forest from further degradation and for the betterment of the socio-economic condition of poor people.

\section{Conclusion}

In this study, we have created various diversified thematic layers in GIS domain and significantly evaluated the spatial pattern and relationship which revealed some interesting trend to make adequate understanding of GHG emission, LULC pattern, vegetation (agriculture and forest) health and future Kharif, Rabi crop season and annual climate changes over India. Such diversified analysis, 
investigation of relationship and a crucial trend of these parameters at the country level of India was never executed in a GIS environment so rigorously in the past.

The total cropland in India is equivalent to $49.6 \%$ of the total geographical area. Around $32.5 \%$ of the total cropland area is used for rice cultivation whereas around $76 \%$ of this rice cultivation is producing high GHG emission (>1000 Mg CO 2 e/yr.) is a matter of serious concern. Agro-Ecological regions are important because it reflects the cropping pattern thus gives a significant correlation with GHG emission (Hou et al., 2012). Agriculture plays an important role in the Indian economy and has diversified socio-economic linkage. It is a major source of income and livelihood for rural India. The climate change significantly maneuvered the weather parameter in terms of its severity which leads to drought, irregular rainfall patterns, floods, and forest fires. These weather severities will adversely affect our agriculture and forest will be reflected in terms of productivity and will be a great challenge as far as food security is concern.

The total forest area for the year 2005 in India was found to be $22 \%$ of the total geographical area. Around 56\% of these forests showed the long-term (1982-2006) negative change trend. Based on various research studies (Chaturvedi et al., 2011; Ravindranath et al., 2012; Chakraborty et al., 2018) it was found the forest of India is deteriorating in term of its greenness, tree density, and quantities and will continue to sink in future. Our study further revealed that the long-term (1982-2006) negative change was found highest (in terms of an area) in the LULC category of 'Deciduous Broadleaf Forest'. Deciduous Broadleaf Forest occupies $43.5 \%$ of the total forest cover of India and significantly harbors the large ethnic tribal community. Apart from several tangible and intangible benefits from the forest, they are the major source of livelihood, income and nourishment for them are severely threatened nowadays and leading to acute poverty. Furthermore, a situation will be more critical in the future due to climate change impact. The study of predicted climate change anomalies shows the significant increase in temperature and variation in rainfall patterns during Kharif and Rabi season will significantly impact the agriculture crop production in the future. So finally we can conclude the climate-smart agriculture (CSA) and REDD+ is the only viable solution will reduce the greenhouse emission, improve the agriculture output, check the deterioration of forest, increase the forest area, and will bring the livelihood resilience by generating the income and mitigate the poverty significantly.

Geospatial technology is one among the finest discipline whereas GIS evaluation in it is the finest approaches to examine large and diversified data sets to analyze the spatial relationship which are highly useful in drawing logical conclusion and significantly support in policy decision making process.

\section{Limitation and future research scope}

The study used a diversified dataset, therefore, the results are showing the circa estimates and can be used with precaution. There is a need for more rigorous studies similar to our study using more diversified data sets including the future climate scenarios and socioeconomic conditions of farmers/poor people/ethnic tribes will significantly reflect more meaningful results.

\section{Acknowledgements}

The authors are grateful to ICAR, India and all websites from where we have downloaded the free dataset and used it in this analysis. 


\section{References}

Ahmad, F., Uddin, M.M. \& Goparaju L. (2018). Agroforestry suitability mapping of India: geospatial approach based on FAO guidelines. Agroforest Syst., 92, 1-18. DOI: 10.1007/s10457-018-0233-7.

Ahmad, F. \& Goparaju L. (2019): Forest fire trend and influence of climate variability in India: a geospatial analysis at national and local scale. Ekológia (Bratislava), 38(1), 49-68. DOI:10.2478/eko-2019-0005.

Anand, A. \& Khetarpal S. (2015). Impact of climate change on agricultural productivity. In B. Bahadur, M.V. Rajam, L. Sahijram \& K.V. Krishnamurthy (Eds.), Plant biology and biotechnology (pp. 729-755). New Delhi: Springer. DOI: $10.1007 / 978-81-322-2286-6 \_30$.

Bandyopadhyay, A., Bhadra, A., Raghuwanshi, N.S. \& Singh R. (2009). Temporal trends in estimates of reference evapotranspiration over India. Journal of Hydrologic Engineering, 14, 508-515. DOI: 10.1061/(ASCE)HE.19435584.0000006 .

Baur, A.H., Forster, M. \& Kleinschmit B. (2015). The spatial dimension of urban greenhouse gas emissions: analyzing the influence of spatial structures and LULC patterns in European cities. Landsc. Ecol., 30, 1195. DOI: 10.1007/s10980-015-0169-5.

Bing, G., Yi, Z., Shi-xin, W. \& He-ping T. (2014). The relationship between Normalized Difference Vegetation Index (NDVI) and climate factors in the Semi-arid Region: A case study in Yalu Tsangpo river basin of Qinghai-Tibet Plateau. Journal of Mountain Science, 11(4), 926-940. DOI: 10.1007/s11629-013-2902-3.

Bothale, R.V. \& Katpatal Y.B. (2014). Response of rainfall and vegetation to ENSO Events during 2001-2011 in Upper Wardha Watershed, Maharashtra, India. Journal of Hydrologic Engineering, 19(3), 583-592. DOI: 10.1061/ (ASCE)HE.1943-5584.0000825.

Byrn, M., Harrison, D., Tong, G. \& Ziemba K. (2013) Mitigating climate change through tropical forests: an analysis of U.S. bilateral REDD+ financing. https:/www.bren.ucsb.edu/research/2013Group_Projects/documents/REDDGPPoster.pdf

Cai, Z.C., Shan, Y.H. \& Xu H. (2007). Effects of nitrogen fertilization on CH4 emissions from rice fields. Soil Sci. Plant Nutr., 53(4), 353-361. DOI: 10.1111/j.1747-0765.2007.00153.x.

Carlson, K.M., Gerber, J.S., Mueller, N.D., Herrero, M., MacDonald, G.K., Brauman, K.A., Havlik, P., O.Connell, Ch.S., Johnson, J.A., Saatchi, S. \& West P.C. (2017). Greenhouse gas emissions intensity of global croplands. Nature Climate Change, 7, 63-68. DOI: 10.1038/nclimate3158.

Chakraborty, A., Seshasai, M.V.R., Reddy, C.S. \& Dadhwal V.K. (2018) Persistent negative changes in seasonal greenness over different forest types of India using MODIS time series NDVI data (2001-2014). Ecological Indicators, 85, 887-903. DOI: 10.1016/j.ecolind.2017.11.032.

Chaturvedi, R.K., Gopalakrishnan, R., Jayaraman, M., Bala, G., Joshi, N.V., Sukumar, R. \& Ravindranath N.H. (2011). Impact of climate change on Indian forests: a dynamic vegetation modeling approach. Mitigation and Adaptation Strategies for Global Change, 16, 119-142. DOI: 10.1007/s11027-010-9257-7.

Dooley, E. \& Chapman S. (2014). Climate-smart agriculture and REDD+ implementation in Kenya. REDD+ Law Project - Briefing Paper. Cambridge: Cambridge Centre for Climate Change Mitigation Research.

Falkenmark, M., Rockstrom, J. \& Karlberg L. (2009). Present and future water requirements for feeding humanity. Food Security, 1, 59-69. DOI: 10.1007/s12571-008-0003-x.

Funk, C.C. \& Brown M.E. (2009). Declining global per capita agricultural production and warming oceans threaten food security. Food Security, 1, 271-289. DOI: 10.1007/s12571-009-0026-y.

Geospatial World (2012). Monitoring agricultural vulnerability using NDVI time series. https://www.geospatialworld. net/article/monitoring-agricultural-vulnerability-using-ndvi-time-series/

GoI (2008). National action plan on climate change. New Delhi: Prime Minister's Council on Climate Change (NAACP). http://www.moef.nic.in/modules/about-the-ministry/CCD/NAP_E.pdf

Gupta, S., Sen, P. \& Srinivasan S. (2012). Impact of climate change on Indian economy: evidence from food grain yields. Delhi: Centre for Development Economics Working Paper 218. DOI: 10.2139/ssrn.2191010

Holben, B.N. (1986). Characteristics of maximum-value composite images from temporal AVHRR data. Int. J. Remote Sens., 7(11), 1417-1434. DOI: 10.1080/01431168608948945.

Hou, H., Peng, S., Xu, J., Yang, S. \& Mao Z. (2012). Seasonal variations of CH4 and N2O emissions in response to water management of paddy fields located in Southeast China. Chemosphere, 89(7), 889-892. DOI: 10.1016/j. chemosphere.2012.04.066.

INCCA (2010). Indian network for climate change assessment. India: Ministry of Environment and Forests, Government of India. 
IPCC (2007). Climate change 2007: Impacts, adaptation and vulnerability. In M.L. Parry, O.F. Canziani, J.P. Palutikof, P.J. van der Linden \& C.E. Hanson (Eds.), Contribution of Working Group II to the Fourth Assessment Report of the Intergovernmental Panel on Climate Change. Cambridge: Cambridge University Press.

IPCC (2014). Climate change 2014 synthesis report summary for policymakers. https://www.ipcc.ch/pdf/assessmentreport/ar5/syr/AR5_SYR_FINAL_SPM.pdf

Lal, M., Cubasch, U., Voss, R. \& Waszkewitz J. (1995) Effect of transient increases in greenhouse gases and sulphate aerosols on monsoon climate. Curr. Sci., 69(9), 752-763.

Lipper, L., Thornton, P., Campbell, B.M., Baedeker, B.M., Braimoh, A., Bwalya, M., Caron, P., Cattaneo, A., Garrity, D., Henry, K., Hottle, R., Jackson, L., Jarvis, A., Kossam, F., Mann, W., McCarthy, N., Meybeck, A., Neufeldt, H., Remington, T., Thi Sen, P., Sessa, R., Shula, R., Tibu, A. \& Torquebiau E.F. (2014). Climate-smart agriculture for food security. Nature Climate Change , 4, 1068-1072. DOI: 10.1038/nclimate2437.

Madhusudhan, L. (2015) Agriculture Role on Indian Economy. Bus. Eco. J., 6(4). DOI: 10.4172/2151-6219.1000176.

Maris, S.C., Teira-Esmatges, M.R. \& Catala M.M. (2016). Influence of irrigation frequency on greenhouse gases emission from a paddy soil. Paddy and Water Environment, 14(1), 199-210. DOI: 10.1007/s10333-015-0490-2.

NAP (2014). National Agroforestry Policy. http://www.indiaenvironmentportal.org.in/files/file/Agroforestry\%20 policy\%202014.pdf

NCAR GIS Program (2012). Climate Change Scenarios, version 2.0. Community Climate System Model, June 2004 version 3.0. http://www.cesm.ucar.edu/models/ccsm3.0/ was used to derive data products. NCAR/UCAR. URL: http://www.gisclimatechange.org.

Nilesh, V. (2018). 46 lakhs hectares of forests in India lost greenness: Study. http://www.newindianexpress.com/states/ telangana/2018/feb/18/46-lakhs-hectares-of-forests-in-india-lost-greenness-study-1775033.html

Pathak, H., Bhatia, A. \& Jain N. (2014). Greenhouse gas emission from Indian agriculture: Trends, mitigation and policy needs. New Delhi: Indian Agricultural Research Institute.

Rao, C.A.R., Raju, B.M.K., Rao, A.V.M.S., Rao, K.V., Rao, V.U.M., Ramachandran, K., Venkateswarlu, B. \& Sikka A.K. (2013). Atlas on vulnerability of Indian agriculture to climate change. Hyderabad: Central Research Institute for Dryland Agriculture.

Ravindranath, N.H., Srivastava, N., Murthy, I.K., Malviya, S., Munsi, M. \& Sharma N. (2012). Deforestation and forest degradation in India: implications for REDD+. Curr. Sci., 102(8), 1-9.

Ray, K.C.S. \& De U.S. (2003). Climate change in India as evidenced from instrumental records. WMO Bulletin, 2(1), 53-59.

Roy, P.S., Roy, A., Joshi, P.K., Kale, M.P., Srivastava, V.K., Srivastava, S.K., Dwevidi, R.S., Joshi, Ch., Behera, M.D., Meiyappan, P., Sharma, Y., Jain, A.K., Singh, J.S., Palchowdhuri, Y., Ramachandran, R.M., Pinjarla, B., Chakravarthi, V., Babu, N., Gowsalya, M.S.,Thiruvengadan, P., Kotteeswaran, M., Priya, V., Murthy, K., Yelishetty, V.N., Maithani, S., Talukdar, G., Mondal, I., Rajan, K.S., Narendra, P.S., Biswal, S., Chakraborty, A., Padalia, H., Chavan, M., Pardeshi, S.N., Chaudhari, S.A., Anand, A., Vyas, A., Reddy, M.K., Ramalingam, M., Manonmani, R., Behera, P., Das, P., Triphati, P., Matin, S., Khan, M.L., Tripathi, O.P., Deka, J., Kumar, P. \& Kushwaha D. (2015). Development of decadal (1985-1995-2005) land use and land cover database for India. Remote Sensing, 7, 2401-2430. DOI: 10.3390/rs70302401.

Sharma, S.K., Choudhary, A., Sarkar, P., Biswas, S., Singh, A., Dadhich, P.K., Singh, A.K., Majumdar, S., Bhatia, A., Mohini, M., Kumar, R., Jha, C.S., Murthy, M.S.R., Ravindranath, N.H., Bhattacharya, J.K., Karthik, M., Bhattacharya, S. \& Chauhan R. (2011). Greenhouse gas inventory estimates for India. Curr. Sci., 101(3), 405-415.

Shukla, P. \& Dhar S. (2016). India’s GHG emission reduction and sustainable development. In S. Nishioka (Ed.), Enabling Asia to stabilise the climate (pp. 41-54). Singapore: Springer. DOI: 10.1007/978-981-287-826-7_3

Sykes, M.T. (2009). Climate change impacts: Vegetation. In Encyclopedia of Life Science (ELS) (pp. 1-11). Chicester: John Wiley and Sons. DOI: 10.1002/9780470015902.a0021227.

UNFCC (2012). United Nations Framework on Climate Change Background (REDD). https://unfccc.int/background

Zarafshani, K., Sharafi, L., Azadi, H. \& Van Passel S. (2016). Vulnerability assessment models to drought: Toward a conceptual framework. Sustainability, 8(6), 588. DOI: 10.3390/su8060588.

Zhao, C., Liu, B., Piao, S., Wang, X., Lobell, D.B., Huang, Y., Huang, M., Yao, Y., Bassu, S., Ciais, P., Durand, J.-L., Elliot, J., Ewert, F., Janssens, I.A., Li, T., Lin, E., Liu, Q., Martre, P., Müller, Ch., Peng, S., Penuelas, J., Ruane, A.C., Wallach, D., Wang, T., Wu, D., Liu, Z., Zhu, Y., Zhu, Z. \& Asseng S. (2017). Temperature increase reduces global yields of major crops in four independent estimates. Proc. Natl. Acad. Sci., 114(35), 9326-9331. DOI: 10.1073/ pnas.1701762114. 